\title{
XXI. Atomic conductivities of the ions
}

\section{Philip Blackman}

To cite this article: Philip Blackman (1906) XXI. Atomic conductivities of the ions, Philosophical Magazine Series 6, 12:68, 150-152, DOI: 10.1080/14786440609463527

To link to this article: http://dx.doi.org/10.1080/14786440609463527

曲 Published online: 16 Apr 2009.

Submit your article to this journal $\pi$

Џll Article views: 2

Q View related articles ¿

4 Citing articles: 1 View citing articles ๘ 


\section{$\left[\begin{array}{ll}150 & ]\end{array}\right.$ \\ XXI. Atomic Conductivities of the Ions. By Philip Blackman*.}

$T$ WHE fact that there exists a definite quantitative relation between molecular conductivities (Phil. Mag. 1906, xi. p. 416 ; Ostwald's Lehrbuch der Alg. Chemie, II. i. p. 672) seems to indicate unmistakably that molecular conductivities are additive properties, $i$. e., that the molecular conductivity of any substance (in aqueous solution) is equal to the sum of the atomic conductivities of its constituent ions. No such regularity apparently exists between the molecular conductivities of the acids, but if the assumption be made that the atomic conductivity of the $\mathrm{H}^{*}$ ion is a function of the relative strengths of acids, then it is possible to calculate its value, and consequently those of other ions.

It was shown (Phil. Mag. 1906, xi. p. 417) that in the general equation

$$
\boldsymbol{\mu} v_{\mathrm{IIX}}+\mu v_{\mathrm{M}_{1} \mathrm{OH}}-\mu v_{\mathrm{M}_{1} \mathrm{x}}=\mathrm{K},
$$

the disappearance of molecular conductivity was equivalent to that required by the equation $\mathrm{H}^{\circ}+\mathrm{OH}^{\prime}=\mathrm{H} . \mathrm{OH}$ for the particular acid in question. 'Then, according to the preceding argument, the atomic conductivity $\left(\mu v_{\mathrm{H}}\right)$ of the $\mathrm{H}^{*}$ ion may be determined from the equations

$$
\begin{aligned}
& \mathrm{R} v_{\mathrm{HX}} \cdot \mu v_{\mathrm{H}}+\mu v_{\mathrm{OH}}=\mathrm{K}, \\
& \mathrm{R} v_{\mathrm{IIx}} \cdot \mu v_{\mathrm{II}}+\mu v_{\mathrm{OH}}=\mathrm{K}_{1}, \\
& \mathrm{R} v_{\mathrm{Hx}_{2}} \cdot \mu v_{\mathrm{H}}+\mu v_{\mathrm{OH}}=\mathrm{K}_{2}, \\
& \ldots \ldots \ldots \ldots \ldots \ldots
\end{aligned}
$$

(in which $\mathrm{R} v_{\mathrm{HX}}, \mathrm{R} v_{\mathrm{HX}}, \mathrm{R} v_{\mathrm{HX}_{2}}$, etc., represent, respectively, the relative strengths of the acids $\mathrm{HX}, \mathrm{HX}_{1}, \mathrm{HX}_{2}$, etc., all measured at the same concentration, $v$, and at the same temperature).

The calculations effected by means of these equations are so fairly consistent that the assumptions made above may very reasonably be taken as correct.

$A$ s an example, the atomic conductivities of the ions $\mathrm{H}^{\circ}$, $\mathrm{OH}^{\prime}, \mathrm{K}^{\circ}$, and $\mathrm{Cl}^{\prime}$, at $18^{\circ}$ and at concentration $v=500$, are worked out in full.

$$
\begin{gathered}
\mathrm{R}_{\mathrm{HCl}}, \mathrm{R}_{\mathrm{HNO}_{3}}, \mathrm{R}_{\frac{1}{2} \mathrm{H}_{2} \mathrm{SO}_{4}}, \mathrm{R}_{\frac{1}{2} \mathrm{H}_{2} \mathrm{C}_{2} \mathrm{O}_{4}} \text {, and } \mathrm{R}_{\mathrm{CH}_{3} \mathrm{CO}_{2} \mathrm{II}} \\
\text { Communicated by the Author. }
\end{gathered}
$$


are respectively $1 \cdot 0,0.9946,0.94,0.46$, and 0.08 ;

$$
\mathrm{K}_{\mathrm{HCl}}, \mathrm{K}_{\mathrm{HNO}_{3}}, \mathrm{~K}_{\frac{1}{2} \mathrm{H}_{2} \mathrm{SO}_{4}}, \mathrm{~K}_{\frac{1}{2} \mathrm{Ir}_{2} \mathrm{C}_{2} \mathrm{O}_{4}} \text {, and } \mathrm{K}_{\mathrm{CH}_{3} \mathrm{CO}_{2} \mathrm{H}}
$$

are respectively $474,472,456,285$, and 163 .

$$
\begin{gathered}
\text { Hence } 1.0 \mu_{\mathrm{H}}+\mu_{\mathrm{OH}}=474,0.9946 \mu_{\mathrm{H}}+\mu_{\mathrm{OH}}=472, \\
0.94 \mu_{\mathrm{H}}+\mu_{\mathrm{OH}}=456,0.46 \mu_{\mathrm{H}}+\mu_{\mathrm{OH}}=285, \\
\text { and } \quad 0.08 \mu_{\mathrm{B}}+\mu_{\mathrm{OH}}=163 .
\end{gathered}
$$

\begin{tabular}{|c|c|c|c|c|c|c|c|c|c|}
\hline$v\left(\right.$ at $\left.18^{\circ}\right)=$ & 1000 & 500 & 200 & 100 & 50 & 20 & 10 & 2 & 1 \\
\hline $\mathrm{H} \ldots$ & 337 & 336 & 333 & 330 & 329 & 323 & 313 & 291 & 270 \\
\hline & 90 & 89 & 87 & 85 & 85 & 81 & 77 & $\ldots$ & 71 \\
\hline $\mathrm{Cs} \ldots \ldots \ldots$ & 91 & 89 & 87 & 85 & & & 76 & & \\
\hline $\mathrm{K} \ldots \ldots \ldots$ & 89 & 89 & 88 & 86 & 83 & 80 & 78 & 67 & 63 \\
\hline $\mathrm{NH}_{3} \ldots \ldots$ & 85 & 84 & 82 & 80 & 78 & 75 & 72 & 64 & 63 \\
\hline${ }^{\mathrm{T}} \mathrm{Tl} . . . . . . .$. & 85 & 85 & 82 & 77 & 76 & 76 & 76 & & \\
\hline$\frac{1}{2} \mathrm{Ba} \quad \ldots \ldots$ & 75 & 75 & 69 & 66 & 65 & 57 & 52 & 40 & 36 \\
\hline$\frac{1}{3} \mathrm{~Pb} \quad \ldots .$. & 76 & 73 & 69 & 63 & 59 & 49 & 41 & 19 & 14 \\
\hline$\frac{1}{2} \mathrm{Sr} \ldots \ldots \ldots$ & 74 & 70 & 67 & 62 & 61 & 55 & 54 & 36 & 30 \\
\hline $\mathrm{Ag}$ & 73 & 72 & 70 & 67 & & 62 & 58 & 43 & 40 \\
\hline$\frac{1}{2} \mathrm{Oa} . . . . . .$. & 69 & 66 & 64 & 60 & 60 & 54 & 44 & 34 & 29 \\
\hline $\mathrm{N}_{\mathrm{a}} \ldots$. & 66 & 65 & 64 & 61 & 60 & 59 & 58 & 41 & 38 \\
\hline$\frac{1}{2} \mathrm{Mg} \quad \ldots \ldots$ & 64 & 60 & 56 & 52 & 47 & 42 & 34 & 32 & 28 \\
\hline$\frac{1}{2} \mathrm{Zn} \ldots \ldots \ldots$ & 64 & 60 & 56 & 50 & 45 & 40 & 35 & 29 & 19 \\
\hline$\frac{1}{2} \mathrm{Od} \quad .$. & & & 55 & 46 & 38 & 82 & 26 & 22 & 15 \\
\hline$\frac{1}{2} \mathrm{Cu} \quad \ldots . .$. & 62 & 55 & 48 & 40 & 33 & 27 & 22 & & 13 \\
\hline Li ............ & 56 & 54 & 53 & 52 & 51 & 48 & 45 & 40 & 34 \\
\hline $\mathrm{OH}$ & 143 & 140 & 140 & 139 & 138 & 135 & 127 & 122 & 109 \\
\hline$\frac{1}{2} \mathrm{CO}_{3} \ldots \ldots$ & 45 & 41 & 36 & 32 & 27 & 21 & 15 & 12 & 7 \\
\hline $\mathrm{Cl}$ & 40 & 40 & 40 & 40 & 38 & 37 & 37 & 36 & 31 \\
\hline $\mathrm{NO}_{3} \ldots \ldots$ & 40 & 40 & 40 & 40 & 38 & 37 & 36 & 34 & 28 \\
\hline Br............ & 40 & 39 & 38 & 38 & 38 & 37 & 36 & 36 & $\ldots$ \\
\hline I ... & 39 & 38 & 37 & 37 & 37 & 37 & 36 & 36 & 36 \\
\hline$\frac{1}{2} \mathrm{SO}_{4} \ldots \ldots$ & 37 & 37 & 33 & 32 & 29 & 24 & 22 & 21 & 13 \\
\hline SCN ....... & 30 & 29 & 28 & 28 & 28 & 28 & 26 & 25 & 24 \\
\hline $\mathrm{ClO}_{3} \ldots \ldots$ & 28 & 27 & 26 & 26 & 26 & 24 & 21 & 18 & \\
\hline $\mathbf{F} \ldots \ldots \ldots$ & 21 & 20 & 20 & 20 & 20 & 18 & 16 & 16 & 16 \\
\hline$\frac{1}{2} \mathrm{C}_{2} \mathrm{O}_{4} \ldots \ldots$ & 12 & 12 & 11 & 11 & 9 & 8 & 7 & 6 & 5 \\
\hline$\frac{1}{3} \mathrm{PO}_{4} \ldots \ldots$. & 11 & 1.1 & 11 & 9 & 7 & 6 & 5 & 3 & 2 \\
\hline $\mathrm{IO}_{3} \ldots \ldots$ & 8 & 8 & 7 & 7 & 7 & 5 & 2 & $\dddot{i}$ & \\
\hline $\mathrm{CH}_{3}$ & 7 & 6 & 6 & 6 & 5 & 4 & 2 & 1 & 0.8 \\
\hline
\end{tabular}

By adding all the equations together and solving the resulting equation $4 \cdot 749 \mu_{\mathrm{H}}=1618$, it is found that $\mu_{\mathrm{H}}=340$.

$$
\begin{aligned}
\mu_{\mathrm{OH}} & =\mu_{\mathrm{HOH}}-\mu_{\mathrm{H}} \cdot \mathrm{R}_{\mathrm{HCl}}=474-337=137 ; \\
\mu_{\mathrm{Cl}} & =\mu_{\mathrm{HCl}}-\mathrm{R}_{\mathrm{HCl}} \mu_{\mathrm{H}}=376-1 \cdot 0 \times 337=39 ; \\
\mu_{\mathrm{K}} & =\mu_{\mathrm{KCl}}-\mu_{\mathrm{Cl}}=126-39=87 ; \\
\text { or } \quad \mu_{\mathrm{K}} & =\mu_{\mathrm{rOH}}-\mu_{\mathrm{OH}}=233-137=96, \text { etc. }
\end{aligned}
$$


The letter $\mu$ (strictly speaking denoting "molecular conductivity") has been retained, for the sake of simplicity, to represent also "atomic conductivity." The table has been entirely constructed from the data in Landolt-Börnstein's Physikalisch-Chemische Tabellen (latest, 1905, edition). In all cases, the atomic conductivities given are the means of those obtained by all the possible calculations. To calculate the molecular conductivity of any salt, base, or acid, respectively, the equation $\mu v_{\mathrm{M}}+\mu v_{\mathrm{x}}, \mu v_{\mathrm{M}}+\mu v_{\mathrm{OH}}$, or $\mathrm{R} v_{\mathrm{Hx}}{ }^{\circ} v_{\mathrm{H}}+\mu v_{\mathrm{x}}$, should be employed.

Enst London Technical College, London, E.

XXII. Distribution of the Intensity of the Radiation from Radioactive Sources. By E. Rutrenford, F.R.S., Macdonald Professor of Physics, McGill University, Montreal *

[Plate II.]

$\coprod^{N}$

$\mathrm{N}$ the course of my experiments on the magnetic deflexion of the a rays emitted by the active deposit of radium, a very peculiar pbotographic effect was observed. The experimental arrangement was similar to that described in a previous paper (Phil. Mag. July 1905). The rays from a wire about $1.5 \mathrm{cms}$. long and $0.5 \mathrm{~mm}$. in diameter, made strongly active by exposure in the radium emanation, passed through a slit and fell on a photographic plate placed some distance above the slit. The whole apparatus was exhausted of air, and a strong magnetic field applied so as to bend the pencil of a rays. With a broad slit, comparable in width to the diameter of the active wire, the photographic trace of the $\alpha$ rays on the plate is shown by a black band with sharply defined edges; and the intensity of the photographic impression is approximately uniform over its cross section. With a very narrow slit, however, the pbotographic trace of the rays has a very different appearance.

Fig. 1 A, Pl. II., shows a magnified drawing of such a trace. The outside edges of the band are sharply defined, and the photographic impression falls off rapidly from the outside to the centre, but is most intense at the extreme edges. The trace, at first sight, appears as if it consisted of two dark

* Communicated by the Author, having been read before the American Physical Society, April 1906. 